\title{
HUBUNGAN FAKTOR DEMOGRAFI DAN DUKUNGAN SOSIAL DENGAN KUALITAS HIDUP PASIEN KUSTA MULTIBASILER PASCA MULTY DRUG THERAPY (STUDI KASUS DI RS KUSTA SUMBERGLAGAH MOJOKERTO)
}

\author{
Denyk Eko Meiningtyas ${ }^{1}$, Arief Hargono ${ }^{2}$ \\ ${ }^{1,2}$ Departemen Epidemiologi Fakultas Kesehatan Masyarakat \\ Universitas Airlangga, Kampus C Mulyorejo \\ Alamat Korespondensi: Denyk Eko Meiningtyas \\ Email: denyk.eko.meiningtyas18@gmail.com
}

\begin{abstract}
Leprosy is a complex condition involving the physical health and quality of life of the patient. Measurement of quality of life aims to assess health and health care obtained by patients. Quality of life is closely related to the stigma. Stigma in leprosy patients can decrease the quality of life of leprosy patients. The purpose of this study is to analyze quality of life leprosy patients with post-Multy Drug Therapy at Sumberglagah leprosy hospital Mojokerto Regency. This research was an observational research, using cross sectional research design. A sample of 80 subjects, was taken by consecutive sampling. Secondary data in the form of list of leprosy patients and primary data was obtained by questionnaires. Data was analysed by Chi Square. The result showed that the distribution of leprosy patients was mostly in the productive age group of 49 people (61,3\%), male gender 45 people (56,3\%), low educated 58 people (72,5\%), and had high social support 52 people (65\%). Age factor $(p=0,035)$, education $(p=0,003)$ and social support $(p=0,009)$ have positif correlation with quality of life of leprosy patients. The sex factor $(p=0.623)$ has no relationship with quality of life of leprosy patients. The conclusions of this study were age, education, and social support factors has relationship with the quality of life of patients with post-Multy Drug Therapy mutlibacillary leprosy in Sumberglagah Mojokerto Hospital. Efforts to hold discussion groups for leprosy patients, increase the leprosy confidence of lepers to be active and productive, and conduct health promotion with socialization is expected to improve the quality of life of leprosy patients.
\end{abstract}

Keywords: social support, demographic factors, quality of life

\begin{abstract}
ABSTRAK
Penyakit kusta merupakan kondisi kompleks yang melibatkan kesehatan fisik dan kualitas hidup pasien. Pengukuran kualitas hidup bertujuan untuk penilaian kesehatan dan perawatan kesehatan yang diperoleh oleh penderita. Kualitas hidup berkaitan erat dengan stigma. Stigma yang di dapat penderita kusta dapat menurunkan nilai kualitas hidup penderita kusta. Tujuan penelitian ini adalah menganalisis kualitas hidup pasien kusta pasca Multy Drug Therapy di RS Kusta Sumberglagah Mojokerto. Penelitian ini merupakan penelitian observasional, menggunakan desain penelitian cross sectional. Sampel penelitian sebesar 80 orang, diambil dengan consecutive sampling. Pengumpulan data menggunakan data sekunder berupa daftar pasien kusta dan data primer diperoleh dengan kuisioner. Analisis data yang digunakan Chi Square. Hasil penelitian diketahui distribusi pasien kusta sebagian besar ada pada kelompok umur produktif 49 orang $(61,3 \%)$, berjenis kelamin laki-laki 45 orang $(56,3 \%)$, berpendidikan rendah 58 orang $(72,5 \%)$, dan memiliki dukungan sosial tinggi 52 orang $(65 \%)$. Faktor umur $(p=0,035)$, pendidikan $(p=0,003)$ dan dukungan sosial $(p=0,009)$ memiliki hubungan positif dengan kualitas hidup pasien kusta. Sedangkan faktor jenis kelamin $(p=0,623)$ tidak memiliki hubungan dengan kualitas hidup pasien kusta. Kesimpulan penelitian ini adalah faktor umur, pendidikan, dan dukungan sosial memiliki hubungan dengan kualitas hidup pada pasien kusta mutlibasiler pasca Multy Drug Therapy di RS Kusta Sumberglagah Mojokerto. Upaya mengadakan kelompok diskusi untuk penderita kusta, meningkatkan rasa percaya diri penderita kusta untuk aktif dan produktif, dan mengadakan promosi kesehatan dengan sosialisasi diharapkan dapat meningkatkan kualitas hidup penderita kusta.
\end{abstract}

Kata Kunci: Dukungan Sosial, Faktor Demografi, Kualitas Hidup 


\section{PENDAHULUAN}

Penyakit kusta merupakan salah satu penyakit kulit menular yang di sebabkan oleh infeksi bakteri mycobacterium leprae yang menyerang bagian tubuh seperti kulit, mukosa, tulang dan bagian tubuh yang lainya kecuali saraf pusat. Penyakit kusta tidak hanya menimbulkan masalah medis namun juga pada masalah sosial, budaya, ekonomi, keamanan dan juga ketahanan nasional (Dirjen P2 dan PL, 2012).

Penyakit kusta sampai saat ini masih ditakuti oleh masyarakat, keluarga bahkan sebagian tenaga kesehatan. Penyakit kusta mempunyai masa inkubasi rata-rata 2-5 tahun. Penularan penyakit kusta dapat terjadi apabila Mycobacterium Leprae yang utuh (hidup) keluar dari tubuh penderita dan masuk ketubuh orang lain. Penularan penyakit kusta dapat terjadi apabila Mycobacterium Leprae. Secara teoritis penularan ini dapat terjadi dengan cara kontak yang lama dengan penderita kusta. Stigma negatif yang ada di masyarakat bahwa penyakit kusta menakutkan, sampai menyebut penyakit kusta merupakan penyakit kutukan. Kurang pengetahuan atau kepercayaan yang keliru dalam masyarakat terhadap kusta dan cacat yang ditimbulkan merupakan sebab adanya stigma negatif dalam masyarakat. Stigma negatif dari masyarakat bisa menyebabkan penderita kusta membatasi diri untuk keluar rumah dan bersosialisasi, bahkan untuk berobat (Dirjen P2 dan PL, 2012).

Jumlah penderita kusta yang dilaporkan dari 121 negara di 5 regional WHO sebanyak 175.554 kasus di akhir tahun 2014 dengan 213.899 kasus baru (www.who.int). Indonesia merupakan salah satu negara dengan beban penyakit kusta yang tinggi. Tahun 2012, penemuan penderita baru sebanyak 16.123 orang, tahun 2013 sebanyak 16.856 kasus baru. Berdasarkan data Tahun 2013 didapatkan 14 dari 33 Provinsi di Indonesia memiliki beban kusta tinggi, di antaranya di Provinsi
Jawa Timur (4.132 kasus baru), Jawa Barat (2.180 kasus baru), Jawa Tengah (1.765 kasus baru), Papua (1.180 kasus baru), dan Sulawesi Selatan (1.172 kasus baru) (Pusdatin Kemenkes RI, 2015).

Di Provinsi Jawa Timur prevalensi rate penyakit kusta pada Tahun 2014 masih sebesar 1,07 per 10.000 penduduk. Tahun 2015 sebesar 1,02 per 10.000 penduduk, dan Tahun 2016 1,24 per 10.000 penduduk. Penemuan kasus baru Tahun 2014 sebanyak 4.116 orang, Tahun 2015 sebanyak 3.946 orang, dan Tahun 2016 sebanyak 4.809 orang. (Dinas Kesehatan Provinsi Jawa Timur, 2016).

Penderita kusta baru di kabupaten Mojokerto tahun 2015 yang dilaporkan sebanyak 116 orang dimana kasus $\mathrm{MB}+\mathrm{PB}$ laki-laki sebesar 76 orang dan perempuan sebesar 40 orang (Dinas Kesehatan Kabupaten Mojokerto, 2015). Penyakit kusta merupakan kondisi kompleks yang melibatkan kesehatan fisik dan kualitas hidup pasien. Masalah yang kompleks pada penderita kusta akan berpengaruh terhadap kualitas hidup penderita kusta itu sendiri.

Kualitas hidup adalah persepsi individu terhadap statusnya dalam kehidupan, dalam konteks budaya, sistem nilai dimana mereka berada dan hubungannya terhadap tujuan hidup, harapan, standart, dan lainya yang terkait (WHO, 2002). Kualitas hidup (Quality Of Life) dalam bidang pelayanan kesehatan digunakan untuk menganalisis emosional seseorang, faktor sosial, dan kemampuan untuk melakukan kegiatan dalam kehidupan secara normal (Brooks \& Anderson, 2007).

Penyakit kusta maupun deformitas fisik yang ditimbulkan merupakan sumber terjadinya stigma dan isolasi sosial terhadap pasien maupu keluarganya dalam masyarakat. Kecacatan dan stigma yang dirasakan pasien akan berperan besar dalam penurunan kualitas hidup. Selain itu, stigma negatif penyakit kusta akan menghalangi program kesehatan komunitas yang berkaitan dengan pencegahan, 
diagnosis dini, terapi dan ketaatan berobat pasien kusta (Rinadewi, dkk. 2013).

Penelitian Rahayuningsih (2012) menunjukan hasil bahwa terdapat hubungan yang bermakna antara perceived stigma dengan kualitas hidup dan penghasilan memiliki hubungan paling kuat dengan kualitas hidup. Penelitian Tsutsumi et al (2007) menyebutkan bahwa faktor-faktor yang berkontribusi terhadap penurunan skor kualitas hidup adalah adanya perceive stigma, pendidikan, adanya kecacatan kusta dan penghasilan yang rendah.

Penelitian Pratama (2012) dijelaskan bahwa tingkat kualitas hidup pada pasien kusta buruk sebesar $41,2 \%$ dan tidak ada subjek yang memiliki tingkat kualitas hidup yang baik. Disampaikan juga pada penelitian Maziyya dkk (2016) bahwa persepsi individu, kerentanan dan keseriusan dapat menjadi faktor yang mempengaruhi kualitas hidup penderita kusta.

Kasus kusta baru dan lama yang masih banyak dapat memberikan beban pada pemerintah sehubungan dengan penurunan Quality of Life (QOL) pada Orang Yang Pernah Mengalami Kusta (OYPMK), karena Orang Yang Pernah Menderita Kusta dalam kehidupannya mengalami gangguan kesehatan fisik, gangguan kesejahteraan psikologis, gangguan hubungan sosial dan masalah lingkungan. Hal tersebut bisa berdampak buruk terhadap kualitas hidupnya seperti dalam mobilitas, hubungan interpersonal, dan kegiatan sosial lainya (Ulfa, 2015).

Hasil beberapa penelitian yang sudah disampaikan dapat diketahui bahwa masih adanya stigma yang dapat mempengaruhi kualitas hidup dari pasien kusta. Stigma yang terjadi pada penderita kusta dapat berasal dari teman, tetangga, masyarakat bahkan dapat berasal dari keluarga penderita kusta itu sendiri. Tanpa disadari stigma dapat muncul dari lingkungan sekitar penderita kusta. Stigma positif akan menghasilkan dukungan sosial yang positif. Dukungan sosial yang di alami oleh penderita kusta dapat mempengaruhi kualitas hidupnya. Selain dukungan sosial faktor demografi seperti umur, jenis kelamin, dan pendidikan penderita kusta dapat mempengaruhi kualitas hidup pada penderita itu sendiri.

Tingkat umur yang lebih matang atau dewasa biasanya dapat mengelola kecemasan dan perasaan emosional dengan baik dari pada mereka yang berumur masih muda. Jenis kelamin perempuan umumya lebih sabar dan lebih bijaksana dalam menerima kenyataan terkait sakit kusta yang dialami dari pada laki-laki. Pendidikan yang tinggi tentunya akan memiliki wawasan yang lebih baik dari pada mereka yang memiliki pendidikan rendah. Seseorang dengan pendidikan tinggi akan memiliki jaringan pertemanan lebih luas dari pada mereka yang memiliki pendidikan rendah, dan tentunya bermanfaat dalam semakin luasnya sumber informasi yang dapat diterima oleh penderita kusta. Sehingga perlu dilakukan penelitian untuk melihat hubungan faktor demografi dan dukungan sosial dengan kualitas hidup pada penderita kusta multibasiler pasca Multy Drug Therapy.

Tujuan dari penelitian ini adalah untuk menganalisis hubungan faktor demografi dan dukungan sosial dengan kualitas hidup pasien kusta multibasiler pasca Multy Drug Therapy di RS Kusta Sumberglagah Mojokerto.

\section{METODE PENELITIAN}

Jenis penelitian yang digunakan dalam penelitian ini adalah jenis penelitian observasional dimana peneliti tidak memberikan perlakuan terhadap subjek penelitian, akan tetapi dengan melakukan pengamatan dan menganalisis hubungan antar variabel. Desain yang digunakan dalam penelitian ini adalah dengan pendekatan cross sectional. Variabel yang diteliti dalam penelitian ini adalah faktor demografi, dukungan sosial dan kualitas hidup pada penderita kusta multibasiler. 
Penelitian ini dilaksanakan di Poli Kusta Rumah Sakit Kusta Sumberglagah Mojokerto pada bulan Desember 2017. Populasi pada penelitian ini adalah penderita kusta multibasiler yang di nyatakan sembuh dan terdaftar pada register Poli RS Kusta Sumberglagah Mojokerto. Jumlah populasi pada penelitian ini adalah 124 responden. Sampel pada penelitian ini adalah penderita kusta multibasiler yang dinyatakan sembuh dan terdaftar pada register poli di RS Kusta Sumberglagah Mojokerto yaitu sejumlah 80 orang. Kriteria inklusi pada penelitian ini yaitu usia responden lebih dari 18 tahun. Cara pengambilan sampel yaitu dengan menggunakan non probability sampling jenis Consecutive sampling yaitu dengan menentukan subjek penelitian yang diambil memenuhi kriteria tertentu dari peneliti dan diambil dalam kurun waktu tertentu (Hidayat, 2009).

Variabel pada penelitian ini yaitu kualitas hidup pasien kusta multibasiler sebagai variabel dependen. Faktor demografi pasien kusta multibasiler dan dukungan sosial pasien kusta multibasiler sebagai variabel independen. Sumber data pada penelitian ini yaitu data primer dan data sekunder. Cara pengumpulan data yaitu dengan menggunakan kuisioner WHOQOL-BREF untuk menganalisis kualitas hidup, kuisioner faktor demografi untuk menganalisis faktor demografi, dan kuisioner dukungan sosial untuk menganalisis dukungan sosial. Teknik analisis data univariat dan bivariat pada penelitian ini menggunakan aplikasi komputer. Analisis univariat pada penelitian ini untuk menghitung distribusi frekuensi pada tiap variabel. Analisis bivariat pada penelitian ini untuk mengetahui hubungan pada variabel, yaitu dengan melihat hasil nilai $p$ value.

\section{HASIL}

Berdasarkan kelompok umur diketahui bahwa sebagian besar responden pasien kusta multibasiler berada pada kelompok umur produktif sejumlah 49 orang $(61,3 \%)$. Sedangkan pada kelompok umur tidak produktif sejumlah 31 orang $(38,8 \%)$.

Tabel 1. Distribusi Pasien Kusta Berdasarkan Kelompok Umur di RS Kusta Sumberglagah Mojokerto Tahun 2017

\begin{tabular}{lcc}
\hline \multirow{2}{*}{ Umur } & \multicolumn{2}{c}{ Pasien Kusta } \\
\cline { 2 - 3 } & Jumlah & $\begin{array}{c}\text { Persentase } \\
(\boldsymbol{\%})\end{array}$ \\
\hline Produktif & 49 & $61,3 \%$ \\
\hline $\begin{array}{l}\text { Tidak } \\
\text { Produktif }\end{array}$ & 31 & $38,8 \%$ \\
\hline Total & 80 & $100 \%$ \\
\hline
\end{tabular}

Tabel 2. Distribusi Pasien Kusta Berdasarkan Jenis Kelamin di RS Kusta Sumberglagah Mojokerto Tahun 2017

\begin{tabular}{lcc}
\hline \multirow{1}{*}{$\begin{array}{c}\text { Jenis } \\
\text { Kelamin }\end{array}$} & \multicolumn{2}{c}{ Pasien Kusta } \\
\cline { 2 - 3 } & Jumlah & $\begin{array}{c}\text { Persentase } \\
(\%)\end{array}$ \\
\hline Laki-laki & 45 & $56,3 \%$ \\
\hline Perempuan & 35 & $43,8 \%$ \\
\hline Total & 80 & $100,0 \%$ \\
\hline
\end{tabular}

Tabel 3. Distribusi Pasien Kusta Berdasarkan Tingkat Pendidikan di RS Kusta Sumberglagah Mojokerto Tahun 2017

\begin{tabular}{lcc}
\hline \multirow{2}{*}{$\begin{array}{c}\text { Tingkat } \\
\text { Pendidikan }\end{array}$} & \multicolumn{2}{c}{ Pasien Kusta } \\
\cline { 2 - 3 } & Jumlah & $\begin{array}{c}\text { Persentase } \\
(\%)\end{array}$ \\
\hline Rendah & 58 & $72,5 \%$ \\
\hline Tinggi & 22 & $27,5 \%$ \\
\hline Total & 80 & $100,0 \%$ \\
\hline
\end{tabular}

Berdasarkan jenis kelamin diketahui bahwa sebagian besar responden 
pasien kusta multibasiler pada penelitian ini memiliki jenis kelamin laki-laki sejumlah 45 orang $(56,3 \%)$. Sedangkan pada jenis kelamin perempuan sejumlah 35 orang $(43,8 \%)$.

Berdasarkan tingkat pendidikan diketahui bahwa sebagian besar responden pasien kusta multibasiler pada penelitian ini memiliki tingkat pendidikan rendah sejumlah 58 orang $(72,5 \%)$. Sedangkan pada tingkat pendidikan tinggi diketahui sejumlah 22 orang $(27,5 \%)$.

Tabel 4. Distribusi Pasien Kusta Berdasarkan Dukungan Sosial di RS Kusta Sumberglagah Mojokerto Tahun 2017

\begin{tabular}{lcc}
\hline \multicolumn{1}{c}{ Dukungan } & \multicolumn{2}{c}{ Pasien Kusta } \\
\cline { 2 - 3 } & Jumlah & $\begin{array}{c}\text { Persentase } \\
(\%)\end{array}$ \\
\hline $\begin{array}{l}\text { Dukungan } \\
\text { Sosial }\end{array}$ & 28 & $35 \%$ \\
Rendah & & \\
\hline $\begin{array}{l}\text { Dukungan } \\
\text { Sosial Tinggi }\end{array}$ & 52 & $65 \%$ \\
\hline Total & 80 & $100 \%$ \\
\hline
\end{tabular}

Berdasarkan dukungan sosial diketahui bahwa sebagian besar responden pasien kusta memiliki dukungan sosial yang tinggi sejumlah 52 orang $(65 \%)$. Sedangkan pada dukungan sosial yang rendah diketahui sejumlah 28 orang (35\%). Berdasarkan kualitas hidup diketahui bahwa sebagian besar responden pasien kusta memiliki kualitas hidup baik sejumlah 56 orang $(70 \%)$.
Tabel 5. Distribusi Pasien Kusta Berdasarkan Kualitas Hidup di RS Kusta Sumberglagah Mojokerto Tahun 2017

\begin{tabular}{lcc}
\hline \multicolumn{1}{c}{ Kualitas } & \multicolumn{2}{c}{ Pasien Kusta } \\
\cline { 2 - 3 } & Jumlah & $\begin{array}{c}\text { Persentase } \\
(\%)\end{array}$ \\
\hline Kualitas & 24 & $30 \%$ \\
Hidup & & \\
Kurang & & \\
Baik & & $70 \%$ \\
\hline $\begin{array}{l}\text { Kualitas } \\
\text { Hidup Baik }\end{array}$ & 56 & \\
\hline Total & 80 & $100 \%$ \\
\hline
\end{tabular}

\section{Analisis Bivariat}

Hasil analisis bivariat pada variabel umur dapat dilihat pada tabel 6. Tabel tersebut menunjukan bahwa berdasarkan analisis Chi-Square Test diketahui nilai $p=$ 0,035 , artinya $p$ kurang dari 0,05 . Sehingga dapat disimpulkan bahwa ada hubungan antara kelompok umur dengan kualitas hidup pada pasien kusta multibasiler di RS Kusta Sumberglagah Mojokerto.

Perhitungan nilai $P R$ yaitu 2,21 dengan $C 1955 \%$ yaitu $1,13-4,34$. Sehingga hasil analisis pada variabel umur bisa disimpulkan bahwa seseorang yang memiliki umur produktif beresiko 2,21 kali lebih tinggi untuk mengalami kualitas hidup kurang baik dibandingkan dengan orang yang memiliki umur produktif.

Tabel 6. Hubungan Kelompok Umur Dengan Kualitas Hidup Di RS Kusta Sumberglagah Mojokerto Tahun 2017

\begin{tabular}{lccccc}
\hline \multirow{2}{*}{ Umur } & \multicolumn{2}{c}{ Kualitas Hidup } & & Total & $\begin{array}{c}\text { Asymp. Sig. (2- } \\
\text { sided) }\end{array}$ \\
\cline { 2 - 3 } & Kurang & Baik & & & \\
\cline { 1 - 4 } Tidak Produktif & 14 & 17 & & 49 & \\
& $45,2 \%$ & $54,8 \%$ & $100 \%$ & \multirow{2}{*}{035} \\
Produktif & 10 & 39 & 31 & \\
\cline { 1 - 4 } Total & $20,4 \%$ & $79,6 \%$ & $100 \%$ & \\
& 24 & 56 & & 80 & \\
\hline
\end{tabular}


Tabel 7. Hubungan Jenis Kelamin dengan Kualitas Hidup di RS Kusta Sumberglagah Mojokerto Tahun 2017

\begin{tabular}{lccccc}
\hline \multirow{2}{*}{ Jenis Kelamin } & \multicolumn{2}{c}{ Kualitas Hidup } & & Total & $\begin{array}{c}\text { Asymp. Sig. (2- } \\
\text { sided) }\end{array}$ \\
\cline { 2 - 3 } & Kurang & Baik & & &, 623 \\
\hline Laki-laki & 15 & 30 & & 45 & \\
\hline Perempuan & $33,3 \%$ & $66,7 \%$ & $100 \%$ & \\
& 9 & 26 & 35 & \\
\hline Total & $25,7 \%$ & $74,3 \%$ & $100 \%$ & \\
& 24 & 56 & & 80 & \\
\hline
\end{tabular}

Hasil analisis bivariat pada variabel jenis kelamin dapat dilihat pada tabel 7. Tabel tersebut menunjukan analisis $C h i$ Square Test diketahui nilai $p=0,623$, artinya $p$ lebih dari 0,05 . Sehingga hasil analisisnya dapat disimpulkan bahwa tidak ada hubungan antara jenis kelamin dengan kualitas hidup pada pasien kusta multibasiler di RS Kusta Sumberglagah Mojokerto.

Perhitungan nilai $P R$ (Prevalen Ratio) yaitu 1,2 dengan CI95\% 0,645 2,606 . Hasil penelitian ini diketahui bahwa pada analisis variabel jenis kelamin bisa disimpulkan yaitu seseorang yang berjenis kelamin laki-laki beresiko 1,2 kali lebih tinggi untuk mengalami kualitas hidup kurang baik dibandingkan dengan orang yang berjenis kelamin perempuan.

Hasil analisis bivariat variabel tingkat pendidikan pada pasien kusta dapat dilihat pada Tabel 8. Tabel tersebut menunjukan analisis Chi-Square Test diketahui nilai $p=0,005$, artinya $p$ kurang dari 0,05 . Sehingga hasil analisis variabel tingkat pendidikan disimpulkan bahwa ada hubungan antara tingkat pendidikan pasien dengan kualitas hidup pada pasien kusta multibasiler di RS Kusta Sumberglagah Mojokerto.

Perhitungan nilai $P R$ yaitu 8,7 dengan CI95\% 1,252 - 60,772. Nilai tersebut signifikan atau bermakna karena nilai CI95\% tidak melewati angka 1 . Sehingga hasil analisis pada variabel tingkat pendidikan bisa disimpulkan bahwa seseorang yang memiliki tingkat pendidikan rendah beresiko 8,7 kali lebih tinggi untuk mengalami kualitas hidup kurang baik dibandingkan dengan orang yang memiliki tingkat pendidikan tinggi.

Tabel 8. Hubungan Tingkat Pendidikan dengan Kualitas Hidup di RS Kusta Sumberglagah Mojokerto Tahun 2017

\begin{tabular}{|c|c|c|c|c|}
\hline \multirow{2}{*}{ Pendidikan } & \multicolumn{2}{|c|}{ Kualitas Hidup } & \multirow{2}{*}{ Total } & $\begin{array}{l}\text { Asymp. Sig. (2- } \\
\text { sided) }\end{array}$ \\
\hline & Kurang & Baik & & \multirow{7}{*}{, 005} \\
\hline \multirow[t]{2}{*}{ Rendah } & 23 & 35 & 58 & \\
\hline & $39,7 \%$ & $60,3 \%$ & $100 \%$ & \\
\hline \multirow[t]{2}{*}{ Tinggi } & 1 & 21 & 22 & \\
\hline & $4,5 \%$ & $95,5 \%$ & $100 \%$ & \\
\hline \multirow[t]{2}{*}{ Total } & 24 & 56 & 80 & \\
\hline & $30 \%$ & $70 \%$ & $100 \%$ & \\
\hline
\end{tabular}


Tabel 9. Hubungan Dukungan Sosial Dengan Kualitas Hidup Pasien Kusta Di RS Kusta Sumberglagah Mojokerto Tahun 2017

\begin{tabular}{lcccc}
\hline \multirow{2}{*}{ Dukungan Sosial } & \multicolumn{2}{c}{ Kualitas Hidup } & \multirow{2}{*}{ Total } & \multirow{2}{*}{ Asymp. Sig. } \\
\cline { 2 - 4 } & Kurang & Baik & & \\
\cline { 1 - 4 } Rendah & 14 & 14 & 28 & \\
& $50,0 \%$ & $50,0 \%$ & $100 \%$ & \multirow{2}{*}{009} \\
Tinggi & 10 & 42 & 52 & \\
& $19,2 \%$ & $80,8 \%$ & $100 \%$ & \\
\hline Total & 24 & 56 & $100 \%$ & \\
& $30 \%$ & $70 \%$ & $100 \%$ & \\
\hline
\end{tabular}

Hasil analisis bivariat pada variabel dukungan sosial pasien kusta multibasiler dapat dilihat pada Tabel 9. Tabel tersebut menunjukan bahwa berdasarkan analisis Chi-Square Test diketahui nilai $p=0,009$, artinya $p$ kurang dari 0,05 . Sehingga hasil analisis penelitian pada variabel dukungan sosial pasien kusta multibasiler dapat disimpulkan bahwa ada hubungan antara dukungan sosial pasien kusta multibasiler dengan kualitas hidup pada pasien kusta multibasiler di RS Kusta Sumberglagah Mojokerto.

Perhitungan nilai $P R$ yaitu 2,6 dengan $C I$ 95\% 1,332-5,076. Nilai tersebut signifikan atau bermakna karena nilai $C I$ $95 \%$ tidak melewati angka 1 . Nilai $P R$ lebih dari 1 berarti bersifat resiko. Sehingga hasil analisis pada variabel dukungan sosial bisa disimpulkan bahwa seseorang yang memiliki dukungan sosial rendah beresiko 2,6 kali lebih tinggi untuk mengalami kualitas hidup kurang dibandingkan dengan orang yang memiliki dukungan sosial yang tinggi.

\section{PEMBAHASAN}

\section{Faktor Umur}

Distribusi frekuensi pada variabel umur pada pasien kusta multibasiler di RS Kusta Sumberglagah Mojokerto menunjukan bahwa mayoritas ada pada kelompok umur produktif 15-55 tahun sejumlah 49 orang $(61,3 \%)$. Menurut UU No. 45 tahun 2015 tentang Penyelenggaraan Program Jaminan
Pensiun bahwa usia pertama kali pensiun ditetapkan pada usia 56 tahun. Seseorang yang berusia lebih dari 56 tahun dianggap sudah menurun produktifitasnya untuk menghasilkan suatu produk atau jasa.

Hasil analisis Chi-Square menunjukan nilai $p=0,035$, artinya ada hubungan antara umur dengan kualitas hidup pada pasien kusta di RS Kusta Sumberglagah Mojokerto. Hal ini berbeda dengan penelitian yang disampaikan oleh Slamet dkk., (2015) bahwa umur tidak memiliki hubungan yang bermakna dengan kualitas hidup. Sebagai makhluk sosial setiap manusia tentunya harus bersosialisasi dengan orang lain untuk memenuhi kebutuhan hidup. Orang yang pernah menderita kusta pada usia produktif maupun tidak produktif di tuntut untuk tetap bersosialisasi dengan orang lain dalam pemenuhan kebutuhan hidupnya. Penyakit kusta yang diderita oleh seseorang dapat menimbulkan rasa cemas yang dapat mengganggu aktivitas seharihari. Pada usia produktif merupakan usia seseorang yang masih dapat bekerja untuk menghasilkan produk atau jasa. Seseorang yang menderita penyakit kusta akan membatasi aktifitas dalam bersosialisasi termasuk dalam bekerja.

Menurut Dirjen PP dan PL (2012) faktor penentu terjadi kusta adalah sumber penularan, cara keluar pejamu, cara penularan, cara masuk dalam pejamu, dan pejamu. Penyakit kusta dapat terjadi pada semua umur, anak-anak, dewasa serta lansia. Sehingga umur tidak termasuk dalam faktor penentu terjadinya kusta. 
Penelitian Tsumsumi dkk, (2007) menyebutkan bahwa tidak ada hubungan yang bermakna antara umur dengan kualitas hidup. Namun dengan adanya rasa cemas yang dialami oleh penderita kusta pada kelompok usia produktif yang dapat menyebabkan pembatasan aktifitas seharihari seperti bertemu orang lain, berkumpul dengan teman, bahkan bekerja. Penyakit kusta merupakan penyakit kronis yang menyerang bagian tubuh kecuali saraf pusat. Orang yang menderita kusta tentunya akan mengalami gangguan fungsional tubunya. Hal tersebut dapat menimbulkan rasa kurang percaya diri karana cacat fisik yang dialami oleh penderita kusta sehingga dapat menurunkan kualitas hidup pada penderita kusta.

\section{Faktor Jenis Kelamin}

Distribusi frekuensi pada variabel jenis kelamin mayoritas berjenis kelamin laki-laki sejumlah 45 orang (56,3\%). Hasil perhitungan Chi-Square didapatkan nilai $\mathrm{p}=0,623$, artinya tidak ada hubungan antara jenis kelamin dengan kualits hidup pasien kusta di RS Kusta Sumberglagah Mojokerto. Seperti yang disampaikan oleh peneliti Slamet dkk (2015) bahwa jenis kelamin laki-laki banyak dijumpai dari pada perempuan, namun jenis kelamin tidak berhubungan dengan kualitas hidup pada penderita kusta.

Jenis kelamin laki-laki atau perempuan mempunyai peluang yang sama untuk mengalami kusta. Seperti yang disampaikan oleh Dirjen PP dan PL (2012) bahwa faktor penentu terjadinya kusta adalah sumber penularan, cara keluar dari pejamu, cara penularan, cara masuk kedalam pejamu, dan pejamu. Pernyataan tersebut menunjukan bahwa jenis kelamin tidak mempengaruhi terjadinya penyakit kusta. Peneliti Mankar dkk, (2011) menyebutkan bahwa laki-laki dan perempuan memiliki dampak yang sama terhadap penyakit kusta dalam peran mereka dalam pergaulan bermasyarakat.
Menderita penyakit kusta bisa menjadi ancaman tersendiri bagi laki-laki sehubungan dengan peran laki-laki sebagai kepala keluarga. Seorang kepala keluarga berperan aktif dalam memenuhi kebutuhan hidup keluarga seperti hal nya bekerja. Kepala keluarga yang menderita kusta tidak akan maksimal dalam bekerja sehingga akan menurunkan pendapatan keluarga. Adanya rasa cemas tidak dapat bekerja maksimal untuk memenuhi kebutuhan keluarga dapat menurunkan kualitas hidup pada laki-laki dalam peranya sebagai kepala keluarga. Perempuan cenderung lebih siap dalam menerima keadaan bahwa dirinya menderita kusta. Perempuan dapat lebih baik dalam mengelola perasaan emosional mereka dari pada laki=laki. Sehingga perempuan dapat lebih baik dalam mengelola kualitas hidupnya. Namun perempuan yang menderita kusta akan melakukan pembatasan pada segala aktifitas di lingkungan keluarga, masyarakat bahkan lingkungan pekerjaan yang dapat berdampak pada menurunnya kualitas hidup pada seorang perempuan.

\section{Faktor Tingkat Pendidikan}

Distribusi frekuensi tingkat
pendidikan didapatkan hasil bahwa sebagian besar pasien memiliki tingkat pendidikan rendah sebanyak 58 orang $(72,5 \%)$. Hasil analisis Chi-Square diketahui nilai $p=0,003$, artinya ada hubungan antara tingkat pendidikan dengan kualitas hidup pasien kusta di RS Kusta Sumberglagah Mojokerto. Seperti yang disampaikan peneliti JG An dkk (2010) bahwa pendidikan merupakan salah satu faktor yang dapat mempengaruhi kualitas hidup pasien kusta di Cina.

Teori Lawrence Green dalam Nursalam (2016) disampaikan bahwa yang berkaitan dengan perubahan perilaku seseorang dapat ditentukan oleh faktor predisposisi, faktor enabling, dan faktor reinforcing. Bentuk faktor enabling salah satunya yaitu pendidikan. Pendidikan yang 
didapat oleh seseorang dapat mempengaruhi pola berfikir orang tersebut. Seseorang dengan tingkat pendidikan yang tinggi akan lebih mudah menerima adanya informasi. Selain itu pengetahuan yang luas juga dapat berpengaruh terhadap pola berfikir seseorang. Pendidikan yang tinggi memberikan peluang pada seseorang untuk lebih banyak menerima informasi. Informasi dapat diterima dari berbagai sumber seperti media elektronik, media cetak, internet, poster, leaflet bahkan dari dinformasi yang disampaikan oleh orang lain. Seperti halnya terkait penyakit kusta, dengan adanya informasi tentang penyakit kusta dapat diterima lebih baik oleh seseorang yang memiliki pendidikan tinggi. Pengetahuan dan wawasan yang diterima seseorang dapat membantu mengelola pola berfikir untuk mengurangi bahkan menghindari rasa cemas yang dialami penderia kusta. Mengelola rasa cemas dengan baik dapat meningkatkan kualitas hidup pada penderia kusta.

Penyakit kusta merupakan penyakit yang mengalami gangguan fungsional pada tubuh. Tahap pertama penyakit kusta akan menyerang saraf tepi, kemudian berlanjut menyerang kulit, mukosa mulut, saluran napas bagian atas, sistem retikuloendotial, otot mata, tulang dan testis kecuali saraf pusat. Penanganan yang lambat pada penderita kusta dapat menyebabkan terjadinya kerusakan akut pada fungsi saraf yang berakibat kecacatan. Adanya cacat pada tubuh pasien kusta dapat menimbulkan rasa cemas dan tidak percaya diri dalam hidup bermasyarakat. Cacat tubuh pada pasien kusta dapat menimbulkan stigma pada masyarakat. Stigma negatif sering muncul dalam masyarakat yang kurang memahami tentang penyakit kusta. Masyarakat menganggap penyakit kusta merupakan penyakit kutukan yang dapat menular. Stigma negatif yang muncul dalam masyarakat menyebabkan penderita kusta akan membatasi diri untuk bersosialisasi, bahkan untuk pergi berobat saja mereka takut. Sehingga penderita kusta cenderung hanya berdiam diri saja dan berobat setelah ada reaksi lanjut. Padahal hal tersebut juga akan merugikan penderita karena pengobatan yang terlambat akan menyebakan cacat fisik. Cacat fisik dapat berdampak pada pembatasan diri terhadap aktifitas sehingga menyebabkan kualitas hidup akan menurun.

\section{Dukungan Sosial}

Distribusi frekuensi pada dukungan sosial pada pasien kusta di RS Kusta Sumberglagah Mojokerto mayoritas memiliki dukungan sosial yang tinggi yaitu sejumlah 52 orang $(65 \%)$. Hasil analisis Chi-Square Test (Tabel 5.8) menunjukan nilai $\mathrm{p}=0,009$, artinya ada hubungan antara dukungan sosial dengan kualitas hidup pada pasien kusta di RS Kusta Sumberglagah Mojokerto. Perhitungan nilai $P R$ di dapatkan hasil 2,6 dengan $C I$ $95 \%$ 1,332-5,076. Nilai tersebut tidak melewati angka 1 sehingga nilai tersebut bermakna atau signifikan. Nilai $P R$ lebih dari 1 berarti resiko. Dapat disimpulkan bahwa penderita kusta yang memiliki dukungan sosial rendah beresiko 2,6 kali lebih tinggi mengalami kualitas hidup kurang dibandingkan penderita kusta yang memiliki dukungan sosial yang tinggi.

Hubungan dukungan sosial dengan kualitas hidup pada penelitian ini sesuai dengan penelitian Melisa dkk., (2012) yaitu dukungan sosial yang tinggi pada seseorang akan meningkatkan kualitas hidup orang tersebut, dan adanya hubungan yang bermakna antara dukungan sosial dengan kualitas hidup. Seseorang yang menerima dukungan sosial yang baik akan meningkatkan perasaan lebih percaya diri, lebih dihargai, diperhatikan bahkan merasa di cintai.

Penelitian Tsutsumi dkk., (2007) menyebutkan bahwa hasil penelitian yang dilakukan di Bangladesh menunjukan bahwa ada hubungan stigma yang dialami pasien kusta dengan kesehatan mental. Kesehatan mental merupakan penentu dari kualitas hidup seseorang. Kesehatan 
mental seseorang baik bila orang tersebut merasa tentram, tenang dan bahagia dengan hidupnya tentunya akan berdampak pada kualitas hidup juga. Kesehatan mental yang baik tentunya akan meningkatkan kualitas hidup.

Penelitian Brakel dkk., (2012) menyebutkan bahwa perceive stigma yang dialami seseorang dapat menyebabkan stress, kecemasan, depresi, bahkan usaha untuk bunuh diri. Kusta merupakan penyakit yang mengalami gangguan fungsional pada anggota tubuh. Seseorang yang menderita kusta akan merasa terganggu karena cacat fisik yang ditimbulkan oleh penyakit kusta tersebut, sehingga penderita kusta akan membatasi diri dalam bersosialisasi dengan lingkungan sekitarnya. Membatasi diri dalam bersosialisasi dengan masyarakat ditambah dengan adanya stigma negatif pada penderita kusta akan berdampak menurunya kualitas hidup penderita kusta, karena penderita kusta akan merasa terisolasi dan tidak bebas untuk melakukan aktivitas seperti masyarakat lainya.

Penelitian Yen dkk., (2009) menyebutkan bahwa seseorang yang mengalami depresi karena stigma pada diri sendiri buruk akan memiliki kualitas hidup yang rendah. Seseorang yang menderita kusta akan merasa hidupnya telah berakhir karena sakit kusta. Penderita kusta merasa tidak bisa melakukan apapun seperti layaknya orang normal yang tidak sakit kusta. Merasa tidak bisa bekerja, tidak akan punya pendamping hidup, bahkan merasa tidak punya masa depan. Adanya stigma negatif pada diri sendiri tersebut tentunya akan menurunkan kualitas hidup penderita kusta. Namun sesungguhnya penderita kusta bisa sembuh dengan melakukan pengobatan secara teratur dan cacat kusta bisa dihindari dengan deteksi dini sakit kusta. Seperti yang disampaikan oleh Dirjen PP dan PL., (2012) bahwa pengobatan kusta akan memutus rantai penularan kusta, menyembuhkan sakit kusta, mencegah cacat atau mencegah bertambahnya cacat yang susdah ada.
Menurut Rafferty (2005) beberapa upaya yang bisa dilakukan untuk mengurangi timbulnya stigma yaitu dengan rehabilitasi fisik dan sosial ekonomi. Upaya tersebut dapat bermanfaat untuk meningkatkan harga diri dan status penderita kusta di masyarakat. Berbagi pengalaman dan informasi pada pasien kusta lain dalam konseling kelompok dapat membantu meningkatkan stigma positif pada diri sendiri. Manusia merupakan makluk sosial yang membutuhkan interaksi sosial dalam kehidupan sehari-hari. Timbulnya sakit kusta akan menjadi beban tersendiri pada penderita kusta untuk berinteraksi sosial. Upaya konseling kelompok akan memfasilisasi penderita kusta untuk mendapatkan pengetahuan baru, teman baru, bahkan untuk mendapatkan pekerjaan, sehingga penderita kusta tidak akan merasa sendirian atau merasa terisolasi dengan keadaanya, karena dalam konseling kelompok akan saling menguatkan antar penderita kusta. Tentunya upaya tersebut dapat meningkatakan kualitas hidup seseorang.

\section{SIMPULAN}

Hasil penelitian ditemukan bahwa variabel umur produktif, jenis kelamin laki-laki, tingkat pendidikan rendah dan dukungan sosial yang tinggi memiliki hubungan yang signifikan atau bermakna dengan kualitas hidup pada penderita kusta multibasiler di RS Kusta Sumberglagah Mojokerto. Dukungan sosial yang tinggi pada pasien kusta dapat meningkatkan kualitas hidup pasien kusta itu sendiri. Pasien kusta akan termotivasi untuk melakukan berbagai kegiatan yang dapat memaksimalkan kualitas hidupnya.

Diharapkan untuk tenaga kesehatan lebih maksimal dalam menyampaikan promosi kesehatan terkait penyaki kusta, seperti dengan mengadakan sosialisasi tentang penyakit kusta. Sumber informasi yang didapat masyarakat dapat menambah 
pengetahuan sehingga masyarakat tidak akan salah menilai tentang penyakit kusta.

Diharapkan penderita kusta dapat meningkatkan rasa percaya diri untuk aktif dan produktif dalam kehidupan sehari-hari. Misalnya dengan membuka usaha seperti berdagang. Penderita kusta tidak menutup diri dari lingkungan masyarakat. Diharapkan untuk pemerintah dapat memberikan fasilitas seperti membuat suatu perkumpulan atau kelompok sehingga penderita kusta dapat berbagi informasi, pengalaman, bahkan pekerjaan kepada penderita kusta yang lain.

\section{DAFTAR PUSTAKA}

Brakel WH., Sihombing B., Djarir H., Beise K., Kusumawardhani L., Yulihane R., Kurniasari I., Kasim M., Kesumaningsih Kl., dan Wilder SA., 2012. Disability in people affected by leprosy the role of impairment, activity, sosial participation, stigma and discrimination.

Brooks, B., Anderson, M. A. 2007. Defining quality of nursing work life. nursing economic.

Dinkesprov Jawa Timur, 2016. Profil Kesehatan Provinsi Jawa Timur 2016.

Dinkeskab Mojokerto, 2015. Profil Kesehatan Kabupaten Mojokerto 2015.

Dirjen P2PL, 2012. Pedoman nasional program pengendalian penyakit kusta.

Hidayat, A. 2009. Riset keperawatan dan teknik penulisan ilmiah. Jakarta: salemba medika.

JG An., J-H Ma., SX Xiao., SB Xiao, dan F Yang., 2010. Quality of life in patients with lepromatous leprosy in China. [e-journal] 24 (7):82732.

Kementerian Kesehatan Republik Indonesia. 2015. Profil kesehatan indonesia
Mankar MJ., Joshi SM., Velankar DH., Mhatre RK, and Nalgundwar AN. 2011. Comparative study of the quality of life, knowledge, attitude and belief about leprosy disease among leprosy patients and community members in Shantivan leprosy rehabilitation centre. Maharashtra, India: J Glob Infect Dis. Social Science \& Medicine 64, 2443-2453.

Maziyya, N., Nursalam, N., Mariyanti, H. 2016. Kualitas hidup penderita kusta berbasis teori heatlh belief models (HBM). [e-journal] 1: pp.96-102.

Melisa., Jeavery B., dan Frenly MU., 2012. Hubungan dukungan sosial dengan kualitas hidup pada pasien Tuberkulosis Paru di Poli Paru BLU RSUP Prof. DR. R. D Kandou Manado. Universitas Sam Ratulangi. [e-journal] 1:1.

Nursalam, 2016. Metodologi penelitian ilmu keperawatan. Jakarta: Salemba Medika.

Pratama, S., 2012. Tingkat kualitas hidup pasien kusta yang datang berobat ke RSU DR. Pirngadi Medan. [ejournal] 1698.

Rafferty, J. 2005. Curing the stigma of Leprosy. Leprosy Review Pubmed Journal, 119-126.

Rahayuningsih, E., 2012. Analisis kualitas hidup penderita kusta di puskesmas kedaung. Tesis. Universita Indonesia.

Rinadewi A., Wieke T., dan Sri LM., 2013. Kualitas hidup pasien kusta.Universitas Indonesia

Slamet., Hadyana S., dan Sharon G., 2015. Faktor-faktor yang mempengaruhi quality of life orang yang pernah mengalami kusta di Kabupaten Cirebon. Universitas Padjajaran. [ejournal]

Tsutsumi, A., Izutsu, T., Akramul Islam MD., Maksuda, A., Kato, H., \& Wakai, S. (2007) The quality of life, mental health, and perceived 
stigma of leprosy patients in Bangladesh sosial science \& medicine 64: pp. 2443-2453.

Ulfa F., Dwi MW., dan Pudjo W., 2015. Perbedaan kualitas hidup Orang Yang Pernah Menderita Kusta (OYPMK) yang tergabung dengan kelompok perawatan diri dan OYPMK yang tinggal di wilayah tanpa KPD

WHO. (2010). Global leprosy situation 2010. Weekly epidemiological record 35: pp. 337-348.
WHO. (2002). WHOQOL-SRPB: User manual. Geneva: WHO.

WHO. (2004). The world health organization quality of life (WHOQOL)-BREF.

Yen CF., Cheng CC., Yu L., Tze-Chun Tang., Chih HK., dan Ju-Yu Y., 2009. Association bertween quality of life and self stigma, insight, and adverse effects of medication in patients with depressive disorder. Pubmed Journal. Vol. 26 (11) 1033-1039 